\title{
Identifikasi Tipe Berpikir Peserta Didik dalam Memecahkan Masalah Matematika
}

\author{
Muji Haryo Kusumo', Mega Suliani ${ }^{2}$ \\ 1,2 SMP Negeri 5 Tarakan \\ *email: ${ }^{1}$ mujiharyokusumo@gmail.com, ${ }^{2}$ mega.suliani@yahoo.co.id
}

\begin{abstract}
This study aims to identify the types of students' thinking in solving mathematical problems in terms of mathematical abilities between high, medium, and low. The method that used in this research is a descriptive qualitative approach. Data is obtained from the results of written tests and interviews. The subjects of the study six students consisting of two high-capacity students, two medium-capacity students and two lowability students in grades VIII-5 at SMPN 5 Tarakan, North Kalimantan. The data analysis was done of triangulation data using document analysis results and analysis of interview transcripts. The results of the study indicate that there are differences in the types of thinking of high, medium and low ability students. In this type of high-ability learners thinking in problem solving using a type of conceptual thinking that is the type of thinking that the way to solve the problem using a concept that has been owned of learning outcomes. While the type of thinking learners medium and low ability to solve problems that no decision could be made, because the indicator filled not located on the same kind of thought process.
\end{abstract}

Keywords: Thinking Type; Problem Solving; Mathematical Ability.

\begin{abstract}
Abstrak
Penelitian ini bertujuan untuk mengidentifikasi tipe berpikir peserta didik dalam memecahkan masalah matematika ditinjau dari kemampuan matematika diantara tinggi, sedang, dan rendah. Metode yang digunakan dalam penelitian ini adalah pendekatan kualitatif yang berjenis deskriptif. Data yang diperoleh dari hasil tes tertulis dan wawancara. Subjek penelitian adalah enam orang peserta didik terdiri dari dua peserta didik berkemampuan tinggi, dua peserta didik berkemampuan sedang dan dua peserta didik berkemampuan rendah pada kelas VIII-5 di Sekolah Menengah Pertama Negeri 5 Tarakan, Kalimantan Utara. Analisis data yang dilakukan yaitu triangulasi data dengan menggunakan hasil analisis dokumen dan analisis transkrip wawancara. Hasil dari penelitian menunjukkan bahwa terdapat perbedaan pada tipe berpikir peserta didik berkemampuan tinggi, sedang dan rendah. Pada tipe berpikir peserta didik berkemampuan tinggi dalam menyelesaikan masalah menggunakan tipe berpikir konseptual yaitu tipe berpikir yang cara menyelesaikan masalah menggunakan konsep yang telah dimiliki dari hasil belajar. Sedangkan pada tipe berpikir peserta didik berkemampuan sedang dan rendah dalam menyelesaikan masalah yaitu tidak dapat diambil keputusan, karena indikator yang dipenuhi tidak terletak pada satu jenis proses berpikir yang sama.
\end{abstract}

Kata Kunci: Tipe berpikir, Pemecahan Masalah, Kemampuan Matematika

\section{PENDAHULUAN}

Pembelajaran matematika bertujuan agar peserta didik memiliki kemampuan pemecahan masalah. Hal ini diperjelas dalam permendiknas nomor 22 tahun 2006 menjelaskan bahwa pendekatan pemecahan masalah merupakan fokus dalam pembelajaran matematika di Indonesia. Anggo (2011) berpendapat bahwa pemecahan masalah merupakan bagian menyeluruh dari matematika, bukan merupakan bagian terpisahkan dari matematika. Peserta didik dalam memecahkan masalah harus didorong untuk merefleksikan pikiran mereka sehingga mereka dapat menerapkan dan 
menyesuaikan strategi mereka untuk menghadapi masalah lain dan dalam konteks lainnya. Melalui pemecahan masalah matematika, peserta didik memperoleh cara berpikir, mempunyai rasa ingin tahu dan ketekunan, kepercayaan diri dalam situasi yang asing. Langkah-langkah pemecahan masalah matematika yang sangat popular diberikan oleh Polya (1973), diantaranya (1) memahami masalah, (2) membuat rencana penyelesaian, (3) menyelesaikan rencana penyelesaian, dan (4) memeriksa kembali.

Kemampuan memecahkan masalah memiliki kaitan yang erat dalam kemampuan berpikir. Peserta didik perlu berpikir untuk memecahkan suatu masalah. Berpikir merupakan suatu kegiatan mental manusia dalam mentransformasi informasi untuk memahami sesuatu yang dialami atau mencari jalan keluar dari persoalan yang dihadapi. Ketita berpikir, setiap orang mengalami proses berpikir, dan proses berpikir berhubungan dengan tipe berpikir.

Menurut Siswono (2002) dalam berpikir, orang akan menyusun hubungan antara bagianbagian informasi yang direkam sebagai pengertian-pengertian. Sehingga kemampuan berpikir seseorang dipengaruhi intelegensinya, oleh karenanya ada kaitan antara intelegensi dan proses belajar matematika. Berpikir merupakan aktivitas mental dengan memunculkan ide-ide dan pengetahuan untuk menyelesaikan masalah yang dihadapi seseorang.

Disadari atau tidak, setiap hari manusia dihadapkan dengan masalah. Upu (2003), mengungkapkan bahwa masalah dapat diartikan sebagai pernyataan yang harus dijawab pada saat itu, tetapi belum mempunyai solusi yang jelas. Jadi, masalah memiliki kaitan dengan cara atau prosedur seseorang dalam menyelesaikannya. Berdasarkan pengertian tersebut, maka masalah adalah pernyataan yang harus dijawab pada saat itu, tetapi belum dapat dipecahkan dengan segera dan tidak tahu secara langsung apa yang harus dilakukan untuk menyelesaikannya.

Melalui pemecahan masalah matematika, peserta didik diarahkan untuk mengembangkan kemampuannya antara lain membangun pengetahuan matematika yang baru, memecahkan masalah dalam berbagai konteks yang berkaitan dengan matematika, menerapkan berbagai strategi yang diperlukan, dan merefleksikan proses pemecahan masalah matematika. Semua kemampuan tersebut dapat diperoleh bila peserta didik terbiasa melaksanakan pemecahan masalah menurut prosedur yang tepat, sehingga cakupan manfaat yang diperoleh tidak hanya terikat pada satu masalah yang dipecahkan saja, tetapi juga dapat menyentuh berbagai masalah lainnya serta mencakup aspek pengetahuan matematika yang lebih luas.

Peserta didik dalam kelas mempunyai perbedaan, diantaranya adalah perbedaan dalam hal pengetahuan dan keterampilan atau disebut kemampuan matematis. Menurut Aini 
(2013) kemampuan matematis yaitu pengetahuan dan keterampilan dasar yang diperlukan untuk dapat melakukan manipulasi matematika meliputi pemahaman konsep dan pengetahuan prosedural. Siswono (2008) menambahkan bahwa perbedaan kemampuan peserta didik dalam memahami konsep matematika dapat menyebabkan adanya perbedaan kemampuan peserta didik dalam memecahkan suatu masalah. Sehingga tingkatan kemampuan matematis dapat dibedakan menjadi tiga tingkatan yaitu tingkat kemampuan atas, menengah dan bawah.

Setiap peserta didik memiliki tipe berpikir yang berbeda-beda. Beberapa ahli mengemukakan tentang tipe-tipe berpikir. Menurut Marpaung (1987), dalam pembentukakan algoritma, tipe berpikir peserta didik terbagi menjadi proses berpikir tipe predikatif dan tipe fungsional. Sedangkan Zuhri (1998), mengungkapkan dalam pemecahan masalah, tipe berpikir peserta didik terdiri dari tipe berpikir konseptual, semi konseptual, dan komputasional. Tipe berpikir konseptual adalah tipe berpikir yang selalu menyelesaikan soal dengan menggunakan konsep yang telah dimiliki berdasarkan hasil pelajarannya selama ini. Tipe berpikir semi konseptual adalah tipe berpikir yang cenderung menyelesaikan soal dengan menggunakan konsep tetapi mungkin karena pemahamannya terhadap konsep tersebut belum sepenuhnya lengkap maka penyelesaiannya dicampur dengan cara penyelesaian yang menggunakan intuisi. Sedangkan tipe berpikir komputasional adalah tipe berpikir yang pada umumnya menyelesaikan suatu soal tidak menggunakan konsep tetapi lebih mengandalkan intuisi.

Zuhri (1998), menentukkan beberapa indicator untuk menelusuri masing-masing proses berpikir sebagai berikut: 1) tipe berpikir konseptual: mampu mengungkapkan apa yang diketahui dalam soal dengan kalimat sendiri, mampu mengungkapkan dengan kalimat sendiri dalam soal, dalam menjawab cenderung menggunakan konsep yang sudah dipelajari, dan mampu menyebutkan unsur-unsur konsep diselesaikan. 2) tipe berpikir semi konseptual: Kurang dapat mengungkapkan apa yang diketahui dalam soal dengan kalimat sendiri, kurang mampu mengungkapkan dengan kalimat sendiri yang ditanya dalam soal, dalam menjawab cenderung menggunakan konsep yang sudah dipelajari walaupun tidak lengkap, tidak sepenuhnya mampu menjelaskan langkah yang ditempuh. 3) tipe berpikir komputasional: tidak dapat mengungkapkan apa yang diketahui dalam soal dengan kalimat sendiri, tidak mampu mengungkapkan dengan kalimat sendiri yang ditanya dalam soal, dalam menjawab cenderung lepas dari konsep yang sudah dipelajari, tidak mampu menjelaskan langkah-langkah yang ditempuh.

Indikator-indikator yang digunakan untuk mengidentifikasi tipe berpikir konseptual, semi konseptual, dan komputasional dapat dilihat pada Tabel 1. 
Tabel 1. Tipe Berpikir Setelah Diadaptasi

\begin{tabular}{|c|c|c|}
\hline $\begin{array}{l}\text { Tipe Berpikir Konseptual } \\
\text { (T1) }\end{array}$ & $\begin{array}{l}\text { Tipe Berpikir Semi } \\
\text { Konseptual (T2) }\end{array}$ & $\begin{array}{l}\text { Tipe Berpikir Komputasional } \\
\text { (T3) }\end{array}$ \\
\hline $\begin{array}{l}\text { Mampu menyatakan apa } \\
\text { yang diketahui dalam soal } \\
\text { dengan bahasa sendiri atau } \\
\text { mengubah dalam kalimat } \\
\text { matematika (T1.1) }\end{array}$ & $\begin{array}{l}\text { kurang mampu menyatakan } \\
\text { apa yang diketahui dalam } \\
\text { soal dengan bahasa sendiri } \\
\text { atau mengubah dalam } \\
\text { kalimat matematika (T2.1) }\end{array}$ & $\begin{array}{l}\text { Tidak mampu } \\
\text { menyatakankan apa yang } \\
\text { diketahui dalam soal dengan } \\
\text { bahasa sendiri atau } \\
\text { mengubah dalam kalimat } \\
\text { matematika (T3.1) }\end{array}$ \\
\hline $\begin{array}{l}\text { Mampu menyatakan apa } \\
\text { yang ditanya dalam soal } \\
\text { dengan bahasa sendiri atau } \\
\text { mengubah dalam kalimat } \\
\text { matematika (T1.2) }\end{array}$ & $\begin{array}{l}\text { Kurang mampu menyatakan } \\
\text { apa yang ditanya dalam soal } \\
\text { dengan bahasa sendiri atau } \\
\text { mengubah dalam kalimat } \\
\text { matematika (T2.2) }\end{array}$ & $\begin{array}{l}\text { Tidak mampu menyatakan } \\
\text { apa yang ditanya dalam soal } \\
\text { dengan bahasa sendiri atau } \\
\text { mengubah dalam kalimat } \\
\text { matematika (T3.2) }\end{array}$ \\
\hline $\begin{array}{l}\text { Membuat rencana } \\
\text { penyelesaian dengan lengkap } \\
\text { (T1.3) }\end{array}$ & $\begin{array}{l}\text { Membuat rencana } \\
\text { penyelesaian tetapi tidak } \\
\text { lengkap (T2.3) }\end{array}$ & $\begin{array}{l}\text { Tidak membuat rencana } \\
\text { penyelesaian (T3.3) }\end{array}$ \\
\hline $\begin{array}{l}\text { Mampu menyatakan } \\
\text { langkah-langkah yang } \\
\text { ditempuh dalam } \\
\text { menyelesaikan soal } \\
\text { menggunakan konsep yang } \\
\text { pernah dipelajari (T1.4) }\end{array}$ & $\begin{array}{l}\text { Kurang mampu menyatakan } \\
\text { langkahlangkah yang } \\
\text { ditempuh dalam } \\
\text { menyelesaikan soal } \\
\text { menggunakan konsep yang } \\
\text { pernah dipelajari (T2.4) }\end{array}$ & $\begin{array}{l}\text { tidak mampu menyatakan } \\
\text { langkah-langkah yang } \\
\text { ditempuh dalam } \\
\text { menyelesaiakan soal } \\
\text { menggunakan konsep yang } \\
\text { pernah dipelajari (T3.4) }\end{array}$ \\
\hline $\begin{array}{l}\text { Mampu memperbaiki } \\
\text { jawaban (T1.5) }\end{array}$ & $\begin{array}{l}\text { Kurang mampu } \\
\text { memperbaiki kekeliruan } \\
\text { jawaban (T2.5) }\end{array}$ & $\begin{array}{l}\text { Tidak mampu memperbaiki } \\
\text { kekeliruan jawaban (T3.5) }\end{array}$ \\
\hline
\end{tabular}

Berdasarkan uraian diatas, peneliti tertarik untuk melakukan penelitian yang berkaitan tentang tipe berpikir peserta didik di SMP 5 Tarakan. Tujuan penelitian ini adalah mengidentifikasi tipe berpikir peserta didik dalam memecahkan masalah matematika berdasarkan kemampuan matematika.

\section{METODE}

Penelitian ini merupakan penelitian pendekatan kualitatif yang berjenis deskriptif, karena menggunakan data kualitatif yang memaparkan dan mendeskripsikan serta mengidentifikasi secara jelas mengenai tipe berpikir peserta didik dalam memecahkan masalah matematika ditinjau berdasarkan kemampuan matematika. Penelitian ini mengacu pada hasil tes tulis dan wawancara terhadap subjek terkait dengan cara subjek menyelesaikan tes pemecahan masalah. Instrumen berupa lembar tes pemecahan masalah. Tes pemecahan masalah dilakukan sebanyak tiga tahap, apabila subjek dapat menyelesaikan soal pada tahap I dan II yang berarti hasil analisis menunjukkan kekonsistenan maka tidak perlu lagi diadakan tes pada tahap III. Sedangkan apabila pada tahap I dan tahap II terdapat perbedaan maka di lakukan tahap III sampai data yang diperoleh konstan. 
Subjek dalam penelitian ini adalah peserta didik kelas VIII-5 di Sekolah Menengah Pertama Negeri 5 Tarakan tahun pembelajaran 2018/2019. Pemilihan subjek didasarkan pada hasil nilai UTS sebelumnya. Berdasarkan hasil nilai UTS dikategorikan ke dalam 3 (tiga) kelompok yaitu peserta didik berkemampuan tinggi, sedang, dan rendah yang masing-masing diwakilkan dua orang peserta didik. Kategori kemampuan peserta didik dalam penelitian ini menggunakan kriteria yang diadaptasi dari Sa'dijah (2013). Peserta didik yang memperoleh skor tes kemampuan matematika lebih dari 80 dikelompokkan ke dalam kategori tinggi. Peserta didik yang memperoleh skor tes kemampuan matematika sama dengan atau lebih dari 60 dan kurang dari 80 dikelompokkan ke dalam kategori sedang. Peserta didik yang memperoleh skor tes kemampuan matematika kurang dari 60 dikelompokkan ke dalam kategori rendah.

Peserta didik yang sudah dikelompokkan berdasarkan kategori kemampuan matematikanya kemudian ditetapkan sebagai subjek berdasarkan masukkan dari guru pengajar matematika. Masukkan dari guru berupa kelancaran komunikasi peserta didik dalam mengemukakan gagasan atau pemikirannya. Kemampuan komunikasi sangat penting dalam penelitian ini untuk mengidentifikasi tipe berpikir siwa selama memecahkan masalah.

Pada analisis data kualitatif dilakukan tahap reduksi data yaitu proses penajaman, menggolongkan, membuang data yang tidak perlu dan mengorganisir data mentah yang diperoleh dari lapangan. Pada tahap penyajian data mencakup pengklasifikasian data dan identifikasi data yaitu menuliskan kumpulan data yang terorganisir sehingga memungkinkan untuk menari kesimpulan dari data tersebut. Pada tahap penarikan kesimpulan yaitu menarik kesimpulan mengenai tipe berpikir peserta didik ketika memecahkan masalah matematika yang diberikan. Kesimpulan diperoleh dari indikator tipe berpikir yang dominan. Artinya subjek disimpulkan mempunyai tipe berpikir tertentu jika memenuhi semua indikator tipe berpikir tersebut, jika tidak, maka tipe berpikir peserta didik tersebut tidak dapat dikategorikan.

\section{HASIL DAN PEMBAHASAN}

\subsection{Analisis Tipe Berpikir Peserta Didik Berkemampuan Tinggi}

Hasil analisis tes dan wawancara peserta didik berkemampuan tinggi berdasarkan penyelesaian masalah tahap I dan II seperti pada Tabel 2 yang menunjukkan kesamaan sehingga tidak diperlukan tes masalah tahap III. Berdasarkan hasil analisis, peserta didik memenuhi indikator: mampu menyatakan apa yang deketahui dalam soal dengan menggunakan bahasa sendiri (T1.1), mampu menyatakan apa yang ditanya dalam soal dengan menggunakan bahas sendiri (T1.2), membuat rencana penyelesaian dengan lengkap (T1.3), mampu menyatakan langkah-langkah yang ditempuh dalam soal 
menggunakan konsep yang pernah dipelajari (T1.4), dan mampu memperbaiki jawaban (T1.5). Berikut disajikan dalam Tabel 2 untuk tipe berpikir peserta didik berkemampuan tinggi.

Tabel 2. Analisis peserta didik berkemampuan tinggi

\begin{tabular}{lccc}
\hline Tipe Berpikir & Indikator & Masalah Tahap I & Masalah Tahap II \\
\hline Konseptual & T1.1 & memenuhi & memenuhi \\
& T1.2 & memenuhi & memenuhi \\
& T1.3 & memenuhi & memenuhi \\
& T1.4 & memenuhi & memenuhi \\
& T1.5 & memenuhi & memenuhi \\
\hline
\end{tabular}

Berdasarkan indikator yang dipenuhi tersebut dan berpedoman pada pengklasifikasian tipe berpikir peserta didik pada Tabel 2, maka jenis proses berpikir peserta didik sudah dapat disimpulkan yaitu konseptual. Hal ini sejalan dengan hasil penelitian Komarudin (2015) yang menyatakan bahwa peserta didik berkemampuan tinggi memiliki tipe berpikir prediktif yaitu cara berpikir dengan kecendrungan untuk melihat hubungan antara dua konsep atau lebih dalam mengambil keputusan. Sehingga tipe berpikir konseptual sama hanya dengan berpikir prediktif karena kedua tipe tersebut melibatkan konsep untuk mengambil keputusan. Sejalan juga dengan hasil penelitian Taufik (2019) yang menyatakan bahwa peserta didik tipe climber dalam memecahkan masalah menggunakan tipe berpikir konseptual.

\subsection{Analisis Tipe Berpikir Peserta Didik Berkemampuan Sedang}

Hasil analisis tes dan wawancara peserta didik berkemampuan sedang berdasarkan penyelesaian soal masalah I dan II seperti pada Tabel 3 yang menunjukkan kesamaan, sehingga tidak diperlukan penyelesaian soal masalah III. Berdasarkan hasil analisis tersebut, peserta didik berkemampuan sedang memenuhi indikator: mampu menyatakan apa yang diketahui dalam soal dengan bahasa sendiri (T1.1), mampu menyatakan apa yang ditanya dalam soal dengan bahasa sendiri (T1.2), mampu membuat rencana penyelesaian tetapi tidak lengkap (T2.3), kurang mampu menyatakan langkah-langkah yang ditempuh dalam menyelesaikan soal menggunakan konsep yang pernah dipelajari (T2.4), dan kurang mampu memperbaiki kekeliruan jawaban (T2.5). Berikut disajikan dalam Tabel 3 untuk tipe berpikir peserta didik berkemampuan sedang.

Tabel 3. Analisis peserta didik berkemampuan sedang

\begin{tabular}{cccc}
\hline Tipe Berpikir & Indikator & Masalah Tahap I & Masalah Tahap II \\
\hline Konseptual & T1.1 & memenuhi & memenuhi \\
& T1.2 & memenuhi & memenuhi \\
& T1.3 & tidak memenuhi & tidak memenuhi \\
& T1.4 & tidak memenuhi & tidak memenuhi \\
& T1.5 & tidak memenuhi & tidak memenuhi \\
\hline
\end{tabular}




\begin{tabular}{|c|c|c|c|}
\hline \multicolumn{4}{|c|}{$\begin{array}{r}\text { Mandalika Mathematics and Education Jc } \\
\text { Volume } 2 \text { Nomor 2, Desembe } \\
\text { e-ISSN } 2715-1190 \mid \text { I p-ISSN } 2 \\
\text { DOI: http://dx.doi.org/10.29303/jm.v }\end{array}$} \\
\hline Tipe Berpikir & Indikator & Masalah Tahap I & Masalah Tahap II \\
\hline Semi Konseptual & $\mathrm{T} 2.1$ & tidak memenuhi & tidak memenuhi \\
\hline & $\mathrm{T} 2.2$ & tidak memenuhi & tidak memenuhi \\
\hline & $\mathrm{T} 2.3$ & memehuhi & memehuhi \\
\hline & $\mathrm{T} 2.4$ & memehuhi & memehuhi \\
\hline & $\mathrm{T} 2.5$ & memehuhi & memehuhi \\
\hline
\end{tabular}

Berdasarkan indikator yang dipenuhi tersebut dan berpedoman pada pengklasifikasian tipe berpikir peserta didik yang disajikan pada Tabel 3, maka tipe berpikir peserta didik berkemampuan sedang tidak dapat disimpulkan karena kelima indikator yang dipenuhi tidak terletak pada satu jenis tipe berpikir yang sama. Hal ini sejalan dengan pendapat Barbacena \& Sy (2015) yang menyatakan bahawa pola-pola proses berpikir setidaknya terdiri dari dua kemampuan berpikir dan paling banyak terdiri dari lima keterampilan berpikir. Barbacena \& Sy (2015) melanjutkan bahwa seorang peserta didik memiliki polanya sendiri dalam memecahkan masalah. Namun hal ini bertentangan dari hasil penelitian Sari \& Saragih (2019) yang menyatakan bahwa peserta didik berkemampuan sedang memiliki tipe berpikir konseptual dan semi konseptual sehingga dikategorikan memiliki pemahaman fungsional/komputasional.

\subsection{Analisis Tipe Berpikir Peserta Didik Berkemampuan Rendah}

Hasil analisis tes dan wawancara peserta didik berkemampuan rendah berdasarkan penyelesaian soal masalah I dan II seperti pada Tabel 4 yang menunjukkan kesamaan, sehingga tidak diperlukan penyelesaian soal masalah III. Berdasarkan hasil analisis tersebut, peserta didik berkemampuan rendah memenuhi indikator: kurang mampu menyatakan apa yang diketahui dalam soal menggunakan bahasa sendiri (T2.1), kurang mampu menyatakan apa yang ditanya dalam soal dengan menggunakan bahasa sendiri (T2.2), tidak membuat rencana penyelesaian soal (T3.3), tidak mampu menyatakan langkah-langkah penyelesaian menggunakan konsep yang pernah dipelajari (T3.4), dan tidak mampu memperbaiki jawaban (T3.5). Berdasarkan indikator yang dipenuhi tersebut dan berpedoman pada pengklasifikasian jenis berpikir peserta didik, maka tipe berpikir peserta didik berkemampuan rendah juga tidak dapat disimpulkan, karena kelima indikator yang dipenuhi tidak terletak pada satu jenis proses berpikir yang sama.

Tabel 4. Analisis peserta didik berkemampuan rendah

\begin{tabular}{cccc}
\hline Tipe Berpikir & Indikator & Masalah Tahap I & Masalah Tahap II \\
\hline Semi Konseptual & T2.1 & memenuhi & memenuhi \\
& T2.2 & memenuhi & memenuhi \\
& T2.3 & tidak memenuhi & tidak memenuhi \\
& T2.4 & tidak memenuhi & tidak memenuhi \\
& T2.5 & tidak memenuhi & tidak memenuhi \\
\hline Komputasional & T3.1 & tidak memenuhi & tidak memenuhi \\
& T3.2 & tidak memenuhi & tidak memenuhi \\
\hline
\end{tabular}




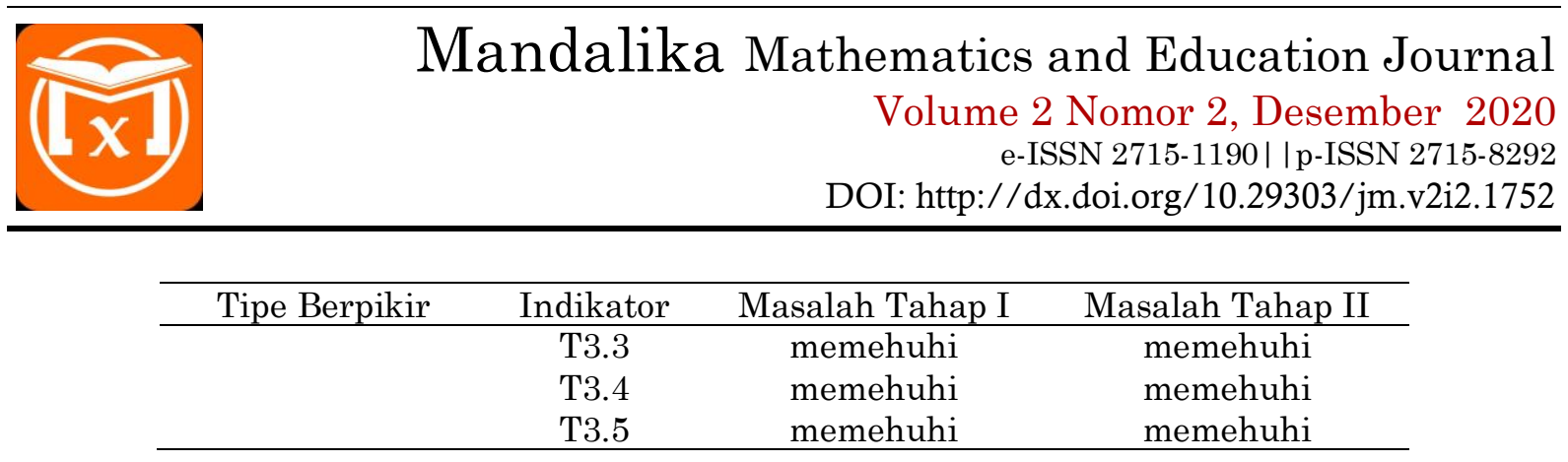

Berdasarkan indikator yang dipenuhi tersebut dan berpedoman pada pengklasifikasian tipe berpikir peserta didik yang disajikan pada Tabel 4, maka tipe berpikir peserta didik berkemampuan rendah tidak dapat disimpulkan karena kelima indikator yang dipenuhi tidak terletak pada satu jenis tipe berpikir yang sama. Sehingga pada Tabel 3 dan 4, tipe berpikir peserta didik berkemampuan sedang dan rendah tidak dapat disimpulkan. Hal ini mungkin karena peserta didik yang terpilih secara random, bukan merupakan peserta didik terendah dari masing-masing kelompok. Hal ini bertentangan dengan hasil penelitian Ramli \& Hidayat (2019) yang menyatakan bahawa peserta didik berkemampuan sedang termasuk kedalam proses berpikir semi konseptual, sedangkan peserta didik berkemampuan rendah termasuk kedalam proses berpikir semi konseptual dan komputasional. Sedangkan menurut hasil penelitian Haniffah \& Manoy menyatakan bahwa peserta didik berkemampuan rendah menggunakan tipe proses berpikir prediktif (konseptual) dan fungsional (komputasional).

\section{PENUTUP}

Berdasarkan hasil yang telah dilakukan terhadap subjek penelitian sebelumnya, maka dapat diketahui tipe berpikir dari tiga subjek penelitian kelas VIII-5 di SMP Negeri 5 Tarakan dalam memecahkan masalah pada materi operasi hitung sebagai berikut.

1. Subjek berkemampuan tinggi mempunyai tipe berpikir konseptual dalam menyelesaikan masalah tahap I dan masalah tahap II.

2. Tipe berpikir peserta didik yang memiliki kemampuan sedang tidak dapat disimpulkan karena kelima indikator yang dipenuhi tidak terletak pada satu jenis proses berpikir yang sama. Baik itu dalam menyelesaikan masalah tahap 1 dan masalah tahap II.

3. Tipe berpikir peserta didik yang memiliki kemampuan rendah tidak dapat disimpulkan karena kelima indikator yang dipenuhi tidak terletak pada satu jenis proses berpikir yang sama. Baik itu dalam menyelesaikan masalah tahap 1 dan masalah tahap II.

\section{REFERENSI}

Aini, I.N. (2013). Meningkatkan Literasi Matematis Siswa Melalui Pendekatan Keterampilan Proses Matematis. (Tesis). Sekolah Pascasarjana, Universitas Pendidikan Indonesia, Bandung.

Anggo, M. (2011). Pelibatan Metakognisi dalam Pemecahan Masalah Matematika. Jurnal Edumatica, 01(1). 
Barbacena, L.B \& Sy, N.R. 2015. Metacognitive model in mathematical problem solving. Journal of the Philippine Council of Mathematics Teacher Educators (MATHTED) Intersection Vol 12.

Haniffah, D. \& Manoy, J. T. (2014). Identifikasi Tipe Berpikir dengan Soal Higher Order Thinking (HOT) ditinjau Berdasarkan Kemampuan Matematika. Jurnal Ilmiah Pendidikan Matematika MATHEdunesa. 3(3). 40-46.

Komarudin. (2015). Analisis Tipe Berfikir dengan Soal Higher Order Thinking ditinjau Berdasarkan Kemampuan Matematika Siswa. Artikel dalam Seminar Nasional Matematika dan Pendidikan Matematika UNY.

Marpaung, Y. (1986). Tipe Berpikir Peserta didik dalam Pembentukan Konsep Algoritma Matematika. Makalah disajikan dalam Pidato Dies Natalis XXXI IKIP Sanata Darma.Yogyakarta.

Polya, G. (1973). How to Solve It, A New Aspect of Mathematical Method. New Jersey: Princeton University Press.

Ramli, A. \& Hidayat, E. (2019). Kemampuan dan Proses Berpikir Reflektif Metematika Peserta Didik Melalui Penerapan Model Pembelajaran Treffinger. Prosiding Seminar Nasional \& Call For Papers Universitas Siliwangi Tasikmalaya.

Sa'dijah, C. (2013). Kepekaan Bilangan Peserta didik SMP Melalui Pembelajaran Matematika Kontekstual yang Mengintegrasikan Keterampilan Berpikir Kreatif. Jurnal Pendidikan dan Pembelajaran (JPP). 20(2). 222-227.

Sari, D. N., \& Saragih, N. A., (2019). Analisis Proses Berpikir Mahasiswa Pendidikan Matematika dalam Menyelesaikan Masalah Matematika Tahun Akademik 2018/2019. Jurnal MathEducation Nusantara. 2(2). 107-112.

Siswono, T. Y. E. (2002). Proses Berpikir Siswa dalam Pengajuan Soal. Konferensi Nasional Matematika XI, 22-25 Juli 2002, Malang.

Siswono, T. Y.E. (2008). Model Pembelajaran Matematika Berbasis Pengajuan dan Pemecahan Masalah untuk Meningkatkan Kemampuan Berpikir Kreatif. Surabaya: Unesa University Press.

Taufik, A. (2019). Sedcription of Thinking Process in Solving Mathematics Problems Based on Brandsford and Stein's Stages Reviewed from Adversity Quotient. Masters Thesis, Universitas Negeri Makassar.

Upu, H. (2003). Problem Posing dan Problem Solving dalam Pembelajaran Matematika. (Pegangan Untuk Guru, Peserta didik PPS, Calon Guru, \& Guru Matematika). Bandung: Pustaka Ramadhan.

Zuhri, D. (1998). Proses Berpikir Peserta didik Kelas II SMP Negeri 16 Pekanbaru dalam Menyelesaikan Soal-Soal Perbandingan Senilai dan Perbandingan Berbalik Nilai. Tesis, tidak dipiblikasikan. Surabaya: UNESA. 